DOI https://doi.org/10.30525/978-9934-26-146-6-7

\title{
ІННОВАЦІЙНЕ ОСВІТНС СЕРЕДОВИЩЕ ЯК СКЛАДОВА ФОРМУВАННЯ ПРОФЕСІЙНОЇ КОМПЕТЕНТНОСТІ МАЙБУТНІХ ФАХІВЦІВ ДОШКІЛЬНОЇ ТА МУЗИЧНОЇ ГАЛУЗІ
}

\author{
Засипкіна Л. А. \\ кандидат педагогічних наук, \\ завідувач кафедри теорії, фахових методик \\ та технологій дошкільної освіти \\ КЗВО «Вінницький гуманітарно-педагогічний коледж»
}

Гаврилюк О. А.

кандидат педагогічних наук,

старший викладач кафедри теорії і методики музичного виховання

КЗВО «Вінницький гуманітарно-педагогічний коледж»

Твердохліб Н. В.

кандидат педагогічних наук,

старший викладач кафедри теорії і методики музичного виховання КЗВО «Вінницький гуманітарно-педагогічний коледж»

м. Вінниця, Україна

В умовах модернізованого ринку праці педагогічних працівників неабиякої актуальності набуває питання підготовки вчителя, його професійного становлення, підвищення рівня професійної компетентності майбутніх фахівців дошкільної та музичної галузі.

В процесі продуктивного професійного становлення майбутніх педагогів-вихователів та музичних керівників закладів дошкільної освіти відбувається розширення кола обов'язків здобувачів освіти, зокрема креативного вирішення професійних педагогічних проблем, що виникають у професійній педагогічній діяльності; накопичування та інтерпретація отриманої інноваційної інформації педагогічного спрямування, застосування інноваційних напрямів педагогічної діяльності у власній практичній діяльності.

Саме тому, завданням закладів професійної педагогічної освіти постає зміна організації роботи вищого навчального закладу, впровадження інноваційних технологій, зокрема створення інноваційного освітнього середовища - використання інноваційних педагогічних технологій в умовах змішаного та дистанційного навчання. 
У педагогічній теорії та практиці питанню створення інноваційного освітнього середовища та використанню інноваційних педагогічних технологій в умовах змішаного та дистанційного навчання присвячено численні грунтовні праці Є. Бачинської, Л. Ващенко, А. Каташова, Л. Кондратової, Н. Разіної, В. Ясвіна, О. Шапран, Ю. Шапран та ін.

Зокрема Н. Разіна, у науковому доробку «Акмеологічний підхід до розвитку професіоналізму сучасного педагога в інноваційному освітньому середовищі середньої школи» дефініціює поняття «інноваційне освітнє середовище» як комплекс взаємопов'язаних умов, які забезпечують освіту людини, формування особистості педагога 3 інноваційно-творчим мисленням, його професійну компетентність [3].

На думку О. Шапран «інноваційне освітнє середовище» $є$ педагогічно доцільно організований простір життєдіяльності, який сприяє розвитку інноваційного ресурсу особистості; інтегрований засіб накопичення i реалізації інноваційного потенціалу навчального закладу. В праці «Створення інноваційного освітнього середовища в процесі професійної підготовки майбутнього вчителя» науковцем визначено структуру інноваційного освітнього середовища та педагогічні умови його ефективного формування [4].

Л. Ващенко потрактовує «інноваційне освітнє середовище окремого регіону» як системне утворення інноваційне середовище окремого регіону, що має власну організаційно-функціональну структуру, основними складовими якого визначено: стратегію розвитку освіти регіону, тактику формування інноваційних процесів, зміст інноваційного середовища регіону, організаційне забезпечення, прогнозування розвитку освіти регіону [1].

У статті Л. Кондратової «Створення інноваційного освітнього середовища для розвитку педагогічної майстерності вчителів музичного мистецтва в післядипломній педагогічній освіті» здійснено детальну характеристику всіх складників інноваційного освітнього середовища в післядипломній педагогічній освіті; розкрито вплив вищеозначеного середовища на розвиток усіх компонентів педагогічної майстерності вчителів музичного мистецтва. Автором проаналізовано цифрові інструменти, платформи, технології для створення інноваційного освітнього середовища [2].

Аналіз першоджерел 3 досліджуваної проблеми дав змогу нам дійти висновку про те, що наукове визначення поняття «інноваційне освітне середовище», зокрема майбутніх педагогів дошкільного та мистецького спрямування, вимагає більш грунтовного дослідження.

Підсумовуючи усі вищеозначені позиції науковців, «інноваційне освітне середовище майбутніх фахівців дошкільного та мистецького 
спрямування» як складової формування їх професійної компетентності визначаємо як системне утворення навчального педагогічного закладу, що передбачає напрями й стратегії розвитку щодо впровадження різного роду інновацій у навчально-виховний процес вищого навчального закладу; наявність готовності здобувачів педагогічної освіти щодо впровадження інновацій у проходженні педагогічної практики в закладах дошкільної освіти та загальноосвітніх школах; вільний відкритий доступ до електронних видань, електронних посібників та онлайн-платформ, впровадження інновацій через забезпечення новітніх електронних засобів навчання в умовах активного розвитку дистанційної освіти, що в свою чергу формуватиме здатність до педагогічної творчості, постійного професійного зросту, педагогічної майстерності педагога-дошкільника та педагога-музиканта, використання інноваційних онлайн-платформ, форм та методів роботи із дошкільниками, школярами, формуватиме творчий характер педагогічної діяльності педагога-дошкільника та учителя музичного мистецтва.

Отже, аналіз психолого-педагогічної літератури дав змогу нам дійти висновку про необхідність подальшого розгляду проблеми створення інноваційного освітнього середовища як складової формування професійної компетентності майбутніх фахівців дошкільної та музичної галузі в умовах коледжної педагогічної освіти, визначення структурних компонентів, педагогічних умов та технології створення дієвого інноваційного освітнього середовища як складової формування професійної компетентності майбутніх фахівців педагогічної сфери.

\section{Література:}

1. Ващенко Л. Інноваційне середовище післядипломної педагогічної освіти. Післядипломна освіта. 2012. № 1. С. 37-40.

2. Кондратова Л. Створення інноваційного освітнього середовища для розвитку педагогічної майстерності вчителів музичного мистетцва в післядипломній педагогічній освіті. Науковий часопис НПУ імені М. П. Драгоманова. С. 126-128.

3. Разіна Н. Акмеологічний підхід до розвитку професіоналізму сучасного педагога в інноваційному освітньому середовищі середньої школи. Вісник наукової школи педагогів «АКМЕ». 2009. В. 3.

4. Шапран О. І. Створення інноваційного освітнього середовища в процесі професійної підготовки майбутнього вчителя. URL: http://www.sportpedagogy.org.ua/html/journal/2010-09/10soitpt.pdf. 